Sveučilište u Splitu, Filozofski fakultet - Odsjek za sociologiju i

Sveučilišni studijski centar za forenzične znanosti;

Odsjek forenzika i nacionalne sigurnosti, Split, Hrvatska

Institut za primijenjena društvena istraživanja

Ivo Pilar - centar, Split, Hrvatska

DOI 10.5937/kultura1236198C

UDK 7.038.531:316.75(497.5)"1968"

7.01:316.75

originalan naučni rad

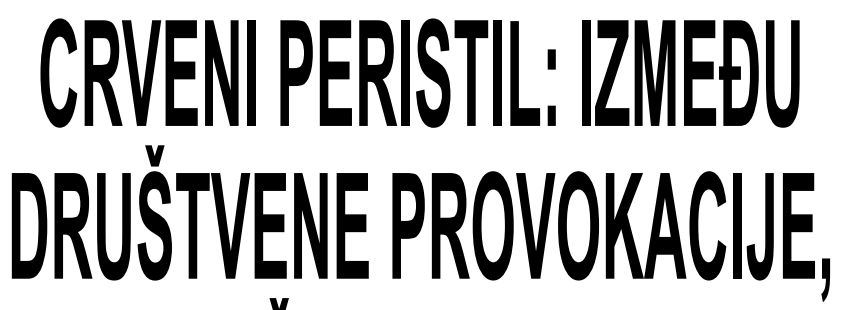
UMJETNCKE NTERVENCIE,

URBANOG MTAI SPLITSKOG JALA

Sažetak: U članku se analizira akcija bojanja splitskoga Peristila iz 1968. godine. Nadalje, razmatraju se kulturološko-civilizacijska obilježja modernih gradova, te duhovna situacija u Splitu 1968. godine. Teorijski se raspravlja o utjecajima kulture, nacije i ideologije na društvenu $i$ duhovnu stvarnost, te općenito o gradu kao mjestu suživota arhitekture, običaja i ljudi. Na temelju brojnih izvora, analizira se akcija bojanja Peristila. Opisuje se način izvođenja akcije, uz prikaz biografija umjetnika koji su u njoj sudjelovali. Pokazalo se da se akteri ni do danas ne mogu složiti tko je činio grupu Crveni Peristil. Prisutne su nesuglasice $i$ oko motiva bojanja Peristila, gdje jedni smatraju da je to bio umjetnički, a drugi ideološko-politički čin. Dat je osvrt na suprotstavljene reakcije javnosti na ovu šokantnu intervenciju. Autori zaključuju da je akcija Crveni Peristil bila važan umjetnički čin, koji je probudio uspavani i apatični Split kasnih 1960-tih, $i$ do danas je ostao samo dijelom razjašnjeni dio urbane mitologije.

Ključne reči: grupa Crveni Peristil, 1968-ma, kultura, nacija, likovna akcija, ideološko-politička akcija 


\section{Uvod}

Revolucionarna 1968-ma u svijetu je prepoznata kao iskorak u postmoderno doba, koji je značio početak postavljanja i ostvarivanja novih imperativa: biti drugačiji, biti jedinstven i biti svoj. Danas se suočavamo sa činjenicom da je tadašnji uzlet pluralizma i individualnosti ,nevidljivom rukom“ skrenut prema uniformnosti i univerzaliziranoj standardizaciji. Međutim, u moru kulturnih klonova postoje izolirani otoci duha umjetnosti koji znaju uzdrmati uljuljani duh naroda, ostavljajući trag ne samo na polju kulture, nego i u društvenoj svakodnevnici. Na tragu navedenoga, gradovi, kao najveći doseg civilizacije ${ }^{1}$, uvijek su mjesto susreta raznih strujanja duha: ,...u monotoniji suvremene civilizacije i gradovi traže svoj identitet, ali taj identitet danas je vrlo teško postići ukoliko ga nisu naslijedili iz prošlosti. Nekada je gotovo svaki grad bio drukčiji, a danas su gotovo svi identični i neprepoznatljivi“2. Što se tiče Splita gdje se dogodio fenomen kojega analiziramo, on ulazi u okvir navedene konstatacije, ali samo u duhovnom smislu u vidu harmonizirane društvene cjeline koja se nerijetko etiketira učmalom i bezličnom. ${ }^{3}$

Davne 1968-me osmorica mladih umjetnika nisu se slagali s navedenom tvrdnjom, a svoj stav o uspavanosti duha grada $i$ monotoničnosti Carskoga trga izrazili su protestom $u$ vidu njegova prebojavanja krvavo crvenom bojom. Taj čin ušao je u kategoriju urbanih legendi, čime je rođen mit o Crvenom Peristilu. Akcija bojanja Peristila u umjetničkim analima ostat će zabilježena kao jedna od prvih konceptualnih akcija koja je šokirala uspavani grad, prodrmavši ga iz temelja. Ona je imala znatno širi odjek i to ne samo na prostoru bivše Jugoslavije, nego i u Europi. Dodatnu dozu misterioznosti i intrige dala je činjenica da do danas nisu razjašnjeni motivi ovoga čina, pogotovo stoga što akteri odbijaju svjedočiti i jasno se izraziti o djelu. S druge strane, složenosti fenomena Crvenog Peristila doprinijeli su činovi suicida i smrti dvaju ključnih aktera, koji su se dogodili pod bizarnim okolnostima. Time su u cijeli slučaj unesene note mistike i okultizma.

1 G. Childe navodi deset kriterija civilizacije koje je našao u civilizacijama Starog i Novog svijeta, gdje na prvo mjesto stavlja velika zbijena naselja odnosno gradove; Čolić S., Kultura i povijest, Zagreb 2002, str. 13-14.

2 Kečkemet D., Borba za grad, Split 2002, str. 406.

3 Povijesna jezgra, a posebno Dioklecijanova palača, predstavlja jedan od ključnih gradskih simbola koji je Splitu priskrbio globalno prepoznatljiv identitet. 


\section{Kultura kao tvorevina duše}

Svakodnevno i uvriježeno određenje pojma kulture podrazumijeva da ,...kultura znači određeno područje koje implicira niz djelatnosti (npr. umjetnost, obrazovanje, znanost) koje nisu izravno vezane za materijalnu proizvodnju, a koje se odnose na tzv. nadogradnju ili ispunjenu dokolicu““4. Na temelju grčkoga i rimskoga shvaćanja kultura je ,...za obrazovane ljude Zapada dobila značenje rafiniranog ukusa, koji se manifestirao u literarnom, emocionalnom i intuitivnom razumijevanju lijepih umjetnosti, kao što su glazba i slikarstvo, zajedno s poznavanjem klasične kulture i suvremene književnosti. Na taj način se naša duhovna kultura odvojila od svakodnevnog života“5. Shvaćanje kulture valja proširiti ostalim relevantnim odrednicama. Prema Durkheimu, “...ukupnost uvjerenja i osjećaja zajedničkih prosječnim građanima istoga društva tvori određeni sustav koji ima vlastiti život; mogli bismo ga nazvati kolektivnom svijesti ili zajedničkom svijesti”'. Tako shvaćena kultura je “...uvijek imala neko obilježje "duhovne kulture""

Ako kulturu percipiramo isključivo kao stanje duha, ${ }^{8}$ tada joj pripisujemo svojstvo ili sredstvo samoostvarenja pripadnika ljudske vrste. U takvom teorijskom okviru pojedinac, kao pripadnik društva, nije pasivni participant odnosno promatrač i primatelj koji u procesu socijalizacije usvaja komponente kulture, već je on aktivni sudionik koji svojim aktivnostima djeluje na promjene kulturnih tradicija. Dapače, svjesnom interakcijom pojedinac može postati glavni čimbenik promjene kulturnih elemenata. Odnos pojedinac-kultura ima dvosmjerni karakter, u kojemu pojedinac i kultura ravnopravno sudjeluju u uzajamnom utjecaju i djelovanju, te zajednički konstruiraju značenja. Tako “...kultura jednog društva jest način života njegovih pripadnika; zbirka ideja i navika što ih uče, dijele i prenose iz naraštaja u naraštaj“c9.

Sustav kulture temelji se na dvije osnovne komponente. Prvu komponentu predstavljaju ustaljene norme, vrijednosti, običaji, vjerovanja i ponašanja. Drugu komponentu čini pojedinac sa svojim individualnim obilježjima, počevši od specifičnosti njegove ličnosti do načina interakcije s tradicionalnim elementima

\footnotetext{
4 Čolić S., Kultura i povijest, Zagreb 2002, str. 10.

5 Ibid.

6 Haralambos M. i Holborn M., Sociologija-teme i perspektive, Zagreb 2002, str. 887

7 Adorno T.W. i Horkheimer M., Sociološke studije, Zagreb 1980, str. 89.

8 Haralambos M. i Holborn M., Sociologija - teme i perspektive, Zagreb 2002, str. 884 .

9 Ibid
} 
kulture. Dakle, kultura je zajednička svim pripadnicima nekog društva. Ona je trajna, prilagodljiva, organizirana i integrirana kategorija, koja ima ulogu propisivanja prihvatljivog ponašanja. Kultura predstavlja adaptivan proces koji je stvoren i koji se prenosi. U tom smislu, jedna od glavnih svrha kulture je dati pripadnicima uvid u spoznaje o prihvatljivim i općeprihvaćenim modelima ponašanja $i$, istovremeno, pružiti im osjećaj pripadnosti i identiteta.

\section{Nacija kao ogledalo duše}

Nacija i nacionalni identitet u suvremenom kontekstu predstavljaju društvene fenomene janusovskog karaktera. Nacionalni identitet jedan je od najizrabljivanijih i najzloupotrebljivanijih pojmova suvremene povijesti koji je, od instrumenta poticanja kohezije unutar društvene zajednice i promicanja zajedničkih vrijednosti i solidarnosti, evoluirao ka instrumentu segregacije pojedinih društvenih skupina. Prema takvom shvaćanju, nacionalni identitet doprinosi jačanju razlikovanja "mi" i "oni" $i$ postaje dezintegracijski element društva. Pojam nacije teško je odvojiti od pojma etnosa jer su oni u visokom stupnju korelacije u smislu egzistiranja u velikom broju mrežnih odnosa. Međutim, treba istaknuti kako je osnovna razlikovna jedinica činjenica da su etničke zajednice nastale gotovo samoniklo (,same od sebe“), dok su nacije stvorene svjesno, često kao umjetne tvorevine koje ne mogu opstati bez specifične ideologije. ${ }^{10}$

Etničke zajednice predstavljaju specifičnu grupu ljudi koja dijeli zajednički jezik i kulturni identitet. U tom smislu ona predstavlja osnovni element diferencijacije prednacionalnih društava i može nastaviti zasebno egzistirati unutar dotične nacije. Dakle, etnička zajednica je uži pojam od nacije, a njene sastavnice su jezik, etnička i kulturna srodnost, te (gotovo uvijek) religija. $\mathrm{Za}$ razliku od nacije, ona nema represivni karakter. Međutim, “...nacionalna demokracija, demokracija nacionalne države, ne počiva na harmoniziranju nego na politički osjetljivim kompromisnim rješenjima proturječja između 'etnosa i demosa'. Prema unutra se razlike i sukobi između etničkih grupa rješavaju uniformiranjem, harmoniziranjem. Put do nacionalne države popločan je potiskivanjem" "11.

Riječ nacija vuče porijeklo iz latinske riječi nasci - biti rođen. Prvotno značenje riječi nacija podrazumijevalo je one pojedince koji su rođeni u istom mjestu, da bi se kasnije značenje postepeno proširilo u smislu označavanja čitavoga naroda jedne zemlje.

10 Beck U., Pronalaženje političkog - prema teoriji refleksivne modernizacije, Zagreb 2001, str. 120.

11 Ibid., str. 125. 
Takvu ideju o grupiranju ljudi na temelju mjesta rođenja možemo smatrati etičkom i filozofskom doktrinom koja predstavlja temelje za stvaranje ideologija, te za manifestacije nacionalizma. Vrcan konstatira kako u žarištu pozornosti “...stoje pitanja o naravi vezivnog tkiva, tj. onoga što jedno mnoštvo ljudi povezuje $u$ naciju te ih pretvara $u$ pripadnike nacije, tj. $u$ pripadnike jedne tzv. sekundarne društvene in-group sa svojstvima tzv. primarne društvene grupe"12. Međutim, “...treba pri tome uvažiti činjenicu da je politika duboko upletena u samo definiranje nacije jer svaka teorijska definicija nacije legitimizira jedne političke zahtjeve, a delegitimizira druge, barem u minimalnom smislu priznavanja ili nepriznavanja njihove društvene normalnosti ili nenormalnosti" "13. Prema navedenome, može se uočiti postojanje dvojbenosti identiteta koja se očituje u činjenici da nacije zahtijevaju lojalnost na osnovama etniciteta, nacionalnosti, religije i/ili ideologije. Pri tome se, u skladu s neonacionalističkim shvaćanjem nacionalizma kao prilagodljive ideologije s mnogo aspekata, “...pitanja identiteta povezuju s pitanjima ekonomske i kulturne moći"14. Na istom tragu je i Jenkinsonova tvrdnja da se društveni identiteti stječu i raspodjeljuju unutar odnosa moći. Stoga je identitet nešto oko čega vlada stalna borba i temelj je stvaranja stratifikacije u društvu. ${ }^{15}$

\section{Ideologija kao suton duše}

Osjećaj pripadnosti i konstrukcija identiteta jedni su od temeljnih čimbenika stabilizacije ličnosti i konzerviranja društvenog konsenzusa. U tom kontekstu je Frommova pretpostavka da čovjek nema svoj vlastiti „društveni kvalitet“ i da je njegova mentalna konstitucija prazan list papira na kojem društvo i kultura upisuju svoj tekst. Osnovni nagoni i glavne strasti su urođeni čovjeku i rezultat su njegove totalne egzistencije. To znači da ih niti jedan dati društveni poredak ne stvara, već samo određuje koji će se čovjekovi nagoni i strasti manifestirati i dominirati. Fromm tvrdi kako se defekt kod osobe javlja ukoliko ona ne ostvari slobodu, spontanost i istinsko izražavanje svoga JA. Kad većina članova društva ne uspije ostvariti navedene elemente, javlja se društveno strukturirani defekt. U tom slučaju individua se ne osjeća izolirano, jer je moguće da je njen defekt kultura uzdiže do vrline. Drugim riječima, kultura ga je strukturirala

12 Vrcan S., Nacija-nacionalizam-moderna država: između etnonacionalizma, liberalnog $i$ kulturnog nacionalizma ili građanske nacije $i$ postnacionalih konstelacija, Zagreb 2006, str. 29.

13 Ibid., str. 81.

14 Haralambos M. i Holborn M., Sociologija-teme i perspektive, Zagreb 2002, str. 267.

15 Jenkins R., Social Identity, London 2007. 
zaštitivši individuu od neuroze od koje bi patila u kulturi koja taj isti defekt smatra neprihvatljivim. ${ }^{16}$

Fromm pod pojmom „društveni karakter“ podrazumijeva bit karakterne strukture koja je zajednička većini članova iste kulture, suprotno individualnom karakteru po kojem se ljudi razlikuju jedni od drugih iako pripadaju istoj kulturi. Društvo kao opći pojam ne postoji, već postoje specifične društvene strukture koje funkcioniraju na različite i utvrđene načine. Dakle, društvo može postojati jedino ako funkcionira u okviru svoje specifične strukture. Funkcija društvenog karaktera je uobličavanje i kanaliziranje ljudske energije u okviru danoga društva, sa svrhom neprekidnog funkcioniranja samog društva. ${ }^{17}$ Kultura omogućava ljudima suživot s defektom, bez opasnosti obolijevanja, a ako bi se uklonili opijumi za društveno strukturirani defekt, na površinu bi izbila bolest. ${ }^{18}$ Navedena intervencija, unatoč mogućim negativnim konotacijama, itekako se treba percipirati dobrodošlom. Naime, opisana društvena maska, koja može prouzročiti nekrozu društvenog tkiva, naziva se ideologijom, ali “...što znači ideologija i što su zapravo ideologije moguće je razumjeti samo ako se prizna povijesno kretanje tog pojma, koje je istodobno $\mathrm{i}$ povijesni razvoj same činjenice"19.

\section{Povijesno kretanje pojma ideologije}

Pojam ideologije karakterizira značenjsko kolebanje odnosno višeznačnost, koje otežavaju njegovo precizno i konačno definiranje. Francuski mislilac Destutt de Tracy ${ }^{20}$ tvorac je ovoga pojma, koji sve do danas izaziva teorijske polemike, ali ima i praktične političke posljedice. Destutt de Tracy ovaj je pojam shvaćao drugačije nego li se on shvaća danas. Za njega je ideologija prvotno bila znanost o idejama koja ,...istražuje podrijetlo ideja, prati njihovo oblikovanje i otkriva zakone po kojima se oni ravnaju“".

Što se tiče suvremenog shvaćanja ideologije, možemo razlikovati dva značenja koja su međusobno odvojiva i objašnjena definicijama koje se ne preklapaju. Prva varijanta značenja pojma ideologije je partikularna. S njome se “... susrećemo (...) kada riječ treba značiti samo to da se ne želi vjerovati određenim „,idejama“ i „predodžbama“ protivnika. Njih se smatra više ili manje svjesnim prikrivanjima nekog stanja stvari čije istinito

16 Fromm E., Zdravo društvo. Zagreb 1989, str. 19-20.

17 Ibid., str. 67-69.

18 Ibid., str. 21.

19 Adorno T.W. i Horkheimer M., Sociološke studije, Zagreb 1980, str. 168.

20 A. Destutt de Tracy (1754-1836) bio je aristokrat, filozof i pripadnik prosvjetiteljstva u školi É. Condillaca, a autor je knjige Elementi ideologije 
spoznavanje nije u protivnikovu interesu. Pritom se može raditi o cijelom rasponu od svjesnog laganja do polusvjesno instinktivnog prikrivanja, od prijevare od strane drugoga do samoza-

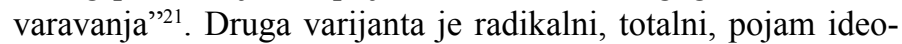
logije, gdje se može “...govoriti o ideologiji neke epohe ili neke povijesno-društveno konkretno određene grupe - recimo neke klase - $\mathrm{u}$ tom smislu da se pritom misli na osebujnost i ustroj totalne strukture svijesti te epohe odnosno tih grupa”. Ono što je zajedničko za obje varijante pojma ideologije je da “...funkcionaliziraju takozvane 'ideje' na nositelja i njegovo konkretno stanje u društvenom prostoru"22.

Mannheim ističe još tri razlikovna elementa:

"Dok partikularan pojam ideologije želi kao ideologije označiti samo dio tvrdnji protivnika, a i taj dio samo s obzirom na njihov sadržaj, totalni pojam ideologije dovodi u pitanje ukupan protivnikov svjetonazor (uključujući i kategorijalni aparat) te želi i te

kategorije razumjeti polazeći od kolektivnog subjekta" ${ }^{23}$.

"Kod partikularnih ideologija funkcionaliziranje se odvija samo na psihološkoj razini. Laži se ovdje još mogu razotkriti, izvori varke još se mogu razbistriti, sumnja u ideologiju ipak još nije radikalna." S druge strane, kod totalnih ideologija funkcionaliziranje se odvija na noološkoj razini: “....ako se kaže da ona epoha živi u onom svijetu ideja, a mi u nekom drugom, ili da onaj povijesno konkretan sloj misli u drukčijim kategorijama nego mi, onda se ne misli samo na sadržaj pojedinačnih misli nego na čitav jedan misaoni sistem, određenu vrstu forme doživljavanja i tumačenja" ${ }^{24}$.

"U skladu s tom razlikom partikularni pojam ideologije prvenstveno barata jednom psihologijom interesa, a totalni mnogo više formaliziranim pojmom funkcije koji se, koliko je moguće, odnosi na objektivne strukturalne povezanosti. U slučaju partikularnog pojma ideologije pretpostavlja se da ovaj ili onaj interes kauzalno prisiljava na tu laž ili prikrivanje, a kod totalnog pojma ideologije smatra se da ovom ili onom mjestu u društvu odgovara ovo ili ono gledište, način promatranja, aspekt... Svako istraživanje ideologije koje počinje na psihološkoj razini (partikularno) u najboljem slučaju može i obuhvatiti razinu kolektivne psihologije. Nasuprot tome, onaj tko se služi totalnim pojmom ideologije, te dakle funkcionalizira sklopove na noološkom području, neće funkcionalizirati s obzirom na neki

21 Mannheim K., Ideologija i utopija, Zagreb 2007, str. 72-73.

22 Ibid., str. 73.

23 Ibid., str. 73-74.

24 Ibid., str. 74. 
psihološki, realan subjekt, nego s obzirom na neki 'subjekt pripisivanja'., ${ }^{25}$

Mannheim smatra da se partikularni i totalni pojam ideologije u realnosti uvijek iznova miješaju. Problem je što još uvijek ne postoji ni idejna, niti sociološka povijest pojma ideologije koja bi analizirala promjene značenja kroz koje je spomenuti pojam prolazio. Kako bilo, smatra se da su opći uvjeti u kojima se stvara lažna svijest (ideologija) stvoreni na prijelazu iz 16. u 17. stoljeće, tj. u počecima stvaranja novovjekovnog građanskog društva. ${ }^{26}$

\section{Identitet grada - suživot arhitekture, običaja i ljudi}

Prethodnim tekstom naznačeno je kako $\mathrm{u}$ istom povijesnodruštvenom kontekstu postoje različito razmještene lažne strukture svijesti, od onih koje u mišljenju prestižu suvremeni bitak do onih koje ga ne uspijevaju dostići. ${ }^{27}$ Ova konstatacija može se primijeniti na naš problem, u smislu da nijedan prostor ne odražava toliku kulturološku i ideološku ambivalentnost i pluralnost kao gradski prostor. Grad je istovremeno mjesto sigurnosti i zaštite ljudskih vrijednosti u kojem se izražava i razvija ljudski duh i snažno diferencirana ličnost, ali je i mjesto represije, kontrole i pokoravanja gradskom autoritativnom normativu, kojega obilježava društvena segregacija, te manifestacije sociološkopatoloških fenomena. Gradsko područje je specifičan prostorni entitet čiji su nastanak uvjetovali mnogobrojni čimbenici (geografski, povijesni, gospodarski, kulturni, sociološki itd). Grad je prostor simbioze odnosno suživota ljudi koji ga nastanjuju, zanata, proizvodnih i uslužnih djelatnosti koji se u njemu odvijaju, susreta svetog i profanog. Grad je mjesto kojem se dodjeljuje i odgojna (socijalizacijska) funkcija, u okviru koje se podučava čovjek njegovoj društvenoj ulozi.

Strukturalisti zauzimaju stajalište kako u osnovi svakog prostornog planiranja, u smislu tendencije izgradnje određenog prostora, leži konstrukcija sustava koji će odražavati diferenciranu

\footnotetext{
25 Ibid.

26 Antidogmatski manifesti F. Bacona za oslobađanje uma navijestili su borbu protiv idola ili kolektivnih predrasuda koji su opterećivali čovječanstvo početkom toga razdoblja, Adorno T.W. i Horkheimer M., Sociološke studije, Zagreb 1980, str. 168. Treba istaknuti kako “...za Bacona idoli znače „lažne bogove“, „predrasude“, i kod njega ih ... ima četiri vrste: idola tribus, idola specus, idola fori, idola theatri. Svi su oni izvori varke i neki od njih potječu od ljudske prirode uopće, a neki od pojedinaca, ali se mogu pripisivati i društvu ili tradiciji te zatvaraju put do istinitog uvida". Mannheim K., Ideologija i utopija, Zagreb 2007, str. 78.
}

27 Mannheim K., Ideologija i utopija, Zagreb 2007, str. 111. 
podjelu "društvenih sadržaja i prostornih izraza". ${ }^{28} \mathrm{~S}$ druge strane, prema Marxu i Engelsu, grad predstavlja aktivni dio naše civilizacije, i u tom smislu može ga se percipirati centrom duhovnih djelatnosti. Navedena percepcija moguća je uslijed tri glavna čimbenika koji su je omogućili:

Prvi čimbenik su ratni pohodi koji su, prema teoriji socijalnog darvinizma, rezultirali nastankom klasnog društva na način da su vojno-osvajačkim pohodima određena plemena pokorila “... druga plemena, pretvarajući sebe u vladajuću elitu ili kastu, a podjarmljena plemena u radnu snagu za svoje potrebe"29.

Navedena ekonomska i duhovna superiornost elite nije bila ostvarena samo putem vojnih pohoda. Drugi je važan čimbenik prva agrarna revolucija koja je, zahvaljujući akumulaciji poljoprivrednih viškova, omogućila uzdržavanje elite i njoj odane vojske.

Treći čimbenik je religijski, kada totemizam ustupa mjesto politeizmu “... jer su se bezlični plemenski totemi personalizirali u bogove i heroje stvorivši nadzemaljsku hijerarhiju koja je regulirala nove društvene odnose" 30 . Tako u gotovo svim antičkim gradovima nailazimo na etničko-religijsku segregaciju “... jer je ona osnova društveno-političkog sistema, pa stoga nužno nameće svoj oblik i gradskoj topografiji. Ona nije nastala spontano već normiranjem. Načelo reda ili harmonije bio je dio svjetonazora koji gleda na društveno uređenje kao na mikrokozmos, na hijerarhijski uređen svijet različitih bića koja po nekim propisanim zakonima moraju stajati u odnosu jedni s drugima"31.

Tradicija poštivanja hijerarhijske uređenosti prostora i normativnog reda, koja je bila narušena ekspanzijom Rima i provalom barbara, ponovno je uspostavljena u srednjem vijeku kao kanon izgradnje grada. Antička tendencija odjeljivanja trgovačkih od administrativno-političkih djelatnosti, te diferencijalizirana raspodjela i razmještaj različitih proizvodnih djelatnosti u pripadajuće gradske kvartove i ulice nastavila se odvijati na prostoru srednjovjekovnog grada. Međutim, tekovine antike i srednjeg vijeka $\mathrm{u}$ vidu uspostave normiranog reda $\mathrm{u}$ gradu opet su bile ugrožene u periodu ekspanzije industrijalizacije i kapitalističkog mentaliteta, koji su grad izložili neredu, nesređenosti i socijalno-patološkim pojavama. Supek to pojašnjava na sljedeći način: "Budući da je prostorni oblik društva njegovo urezivanje

28 Opširnije o tome vidjeti u: Supek R., Društvene predrasude i nacionalizam, Zagreb 1992, str. 13.

29 Ibid., str. 28.

30 Ibid.

31 Ibid., str. 28-29. 
u prostor, društvenost u svojoj prostornosti, to prostorni sistem mora odražavati i proturječnost društvene organizacije, iako određeni dio društvenog sektora može biti u svojem funkcionalnom obliku jako reduciran, kao što je proizvodni rad u punoj automaciji. Mašta se ovdje sudara s vlastitim granicama, s racionalnošću prostorne organizacije“"32. Prema tome, uvijek se radi o asimetričnoj raspodjeli društvene moći koja treba ideološko ili socijalno opravdanje, kako bi je prihvatio što veći broj članova određenog društva. ${ }^{33}$

\section{Bojanjem Peristila 1968-ma je počela u Splitu}

„Šezdeset osma“ smatra se godinom koja je u više navrata uzdrmala svijet, a događaji koji su je obilježili odredili su je kao godinu seksa, droge, rock'n rolla i generacijskog jaza. Bila je to godina Vijetnamskoga rata, atentata na M. Luthera Kinga ml. i B. Kennedya, umjetničkih šokova poput Beatlesa, Warholovog pop-arta i avangardnog kazališta, buđenja revolucionarnog duha svijeta u vidu Praškog proljeća, te studentskih prosvjeda i spontanih ,ustanaka“ diljem Europe. Bila je to, prema mnogima, “... posljednja svjetska eksplozija utopijske energije”, koja se nije ponovila sve do danas. ${ }^{34}$ Šezdesetosmaški studentski pokret bio je svojevremeno optužen za seksualni razvrat, moralni prevrat, naklonost komunizmu (ljevičarenju), itd. Danas se mnogi sa žalom sjećaju tog jedinstvenog iskustva mobilizacije i društvenog angažmana mladih koji je bio, kako smo kazali, svojevrsni uvod u postmoderno stanje, koje je postavilo imperative oslobađanja ljudskog duha od tradicijskih okova. ${ }^{35}$

U takvom duhovnom ozračju osam mladića ${ }^{36}$ odlučilo je u rano jutro 11. siječnja 1968. „biti svojima“ i to prije svih. Naime, iako se u svim prisjećanjima i analizama 1968-me prvenstveno ističu Pariz, Prag, pa i Beograd, smatra se kako je akcija bojanja splitskog Peristila u crveno događaj koji je toj godini dao gotovo mitsko značenje, tim više što se odigrao u središtu grada, u srcu Dioklecijanove palače. Unatoč činjenici da je teško precizirati točan broj sudionika akcije, kao idejni začetnici u većini konzultiranih izvora navode se P. Dulčić, S. Sumić, T. Čaleta,

32 Ibid., str. 15.

33 Ibid., str. 27-28.

34 Vidjeti detaljnije u: Grupa autora, 1968. trideset godina kasnije.

35 Knežević R., Načelo slobode i politički poredak. Politologijski ogledi o liberalizmu, totalitarizmu i demokraciji, Zagreb 2007.

36 Prema nekim izvorima aktera akcije bilo je devet, odnosno dvanaest. Primjerice, Bavčević navodi kako su grupu splitskih umjetnika koja je obojila Peristil činili P. Dulčić, S. Sumić, N. Đapić, T. Čaleta, A. Aljinović, S. Blažević i D. Dokić (dakle sedmorica performera). Bavčević spominje još nekoliko sudionika-pomagača čija imena nisu ostala zabilježena. 
D. Dokić, R. Kogej i B. Jelenić, te još nekoliko "flukturirajućih pojedinaca". Među flukturirajućima posebno je zanimljiva uloga V. Dodiga-Trokuta koji je u kasnijim javnim istupima prisvajao ideju svojom, te J. Laznibata koji se počinje tek nedavno spominjati. ${ }^{37}$ Iako je akcija Crveni Peristil mnoge od sudionika učinila besmrtnima, ona je za neke od njih bila osobno prokletstvo. Razumijevanje navedenog najbolje osvijetlavaju opisi životnoga puta najkontroverznijih sudionika.

\section{Redom, to su:}

Pave Dulčić, spiritus movens splitske konceptualne scene, student likovnoga smjera Pedagoške akademije u Splitu, mladi umjetnik koji je umro od posljedica pokušaja samoubojstva bacanjem pod vlak 1974. g.;

Slaven Sumić, student likovnoga smjera Pedagoške akademije u Splitu, koji se poslije bavio primijenjenom umjetnosti u kazalištu, gdje je izrađivao rekvizite, kostime i scenografije $^{38}$

Tomo Ćaleta, likovni umjetnik i pjesnik, počinio je samoubojstvo 1972. godine skokom sa 13. kata nebodera, stavivši oko vrata natpis "ja sam umjetnik";

\section{Radovan Kogej, splitski "besposličar";}

Vladimir Dodig-Trokut, samoprozvani likovni umjetnik, ,akcionist", performer reciklaža društvene i mentalne angažiranosti, mistik, vidovnjak, paranormalni fenomen, začetnik i vlasnik

$$
\text { Antimuzeja }{ }^{39} \text {; }
$$

Boris Jelenić, koji se smatra duhovnim ocem Crvenog Peristila, bio je jedan od najradikalnijih umjetnika, ne samo u okviru jugoslavenske umjetnosti, nego i znatno šire. Smatran je nezamjenjivim protagonistom (ne)vidljivog kulturnog života. Navedene epitete zavrijedio je specifičnim pristupom umjetnosti, temeljenim na oštroj kritici konvencionalnog kanonskog modela koji je dominirao u praksi većine tadašnjih umjetnika. Bio je avangardist, pop artist i radikalni enformel slikar. Kao srednjoškolski profesor i boem, odgojio je mnoge generacije splitskih umjetnika. ${ }^{40}$

37 J. Laznibat uglavnom se spominje na forumima internet portala hrvatskih tiskovnih medija, iako ga neki smatraju jednim od idejnih začetnika akcije.

38 S. Sumić proveo je dva desetljeća u Kazalištu lutaka, a poslije je djelovao u Hrvatskom narodnom kazalištu, te Gradskom kazalištu mladih u Splitu.

39 Otac V. Dodiga-Trokuta bio je vojno lice u činu pukovnika i jedan od najvećih eksperata za gradnju aerodroma i specijalna vojna miniranja.

40 B. Jelenić prvo je predavao u osnovnoj školi u Solinu, da bi zatim postao profesor u Školi primijenjene umjetnosti u Splitu. U periodu od 1954. 
Osim likovnih umjetnosti, sljedeća poveznica skupine je njihovo članstvo u Kino klubu Split i zaljubljenost u filmsku umjetnost. U splitskoj Školi primijenjene umjetnosti dolazi do prvog kontakta s P. Dulčićem, kojeg B. Jelinić priznaje za svoga teorijskog istomišljenika i koautora akcije Peristil. Prema svjedočanstvima, postoje iskazi o dva glavna motiva inspiracije za bojanje

Peristila:

Teza primarno likovno motivirane akcije: prema S. Sumiæu, ideja je rođena za vrijeme njegovog i Dulčićevog putovanja u Pariz. Fascinirani proživljenim iskustvima, po povratku u Split su donijeli ideju squata i odlučnost da se, praksom nonkonformističkog ponašanja i drukčijim promišljanjem života i umjetnosti, domicilnoj sredini predstave radom kojega će svi zamijetiti. Prvi su u Splitu nosili dugu kosu i bradu, živjeli u napuštenom potkrovlju u Getu ${ }^{41}$ i poduzeli mnoge akcije koje su odskakale od ustaljenih umjetničkih kanona. Prema Sumiću, ideja Crvenog Peristila nastala je za vrijeme Dulčićevog i njegovog boravka u Švedskoj, a tu verziju potvrđuje i V. Dodig-Trokut, koji promovira drugu, političku tezu.

Teza ideološki i politički motivirane akcije: V. Dodig-Trokut zagovara stajalište da se ne radi ni o kakvom radikalnom istupu, već o šali visokopozicioniranih partijskih službenika. Oni su, za vrijeme jednog susreta s P. Dulčićem i ostalima, komentirali kako bi bilo lijepo da Split, po uzoru na Moskovski Crveni trg, ima svoj crveni Peristil. ${ }^{42}$ Prema ovoj verziji, „šala“ je realizirana nakon dvije godine. Ubrzo se pokazalo da bi akcija motivirana isključivo šalom mogla prerasti u akciju u kojoj dominiraju ideološke konotacije i politički angažman, kao izravan napad na tadašnji sustav krutog socijalizma. ${ }^{43}$ Umjetnički alibi navedenoj politički potencijalnoj prijetnji dao je F. Roje objavivši 1968.

do 1955. god. radio je pješčane slike i prvi u svijetu je formirao pješčani ambijent.

41 Da u Dioklecijanovoj palači nisu živjeli Židovi, ne bi postojao prostor kojega su Splićani nazvali Get. Smatra se da su Židovi u Palači živjeli puno prije Hrvata, već u doba Dioklecijana. U Palači su prisutniji od 7. stoljeća, nakon što su Avari u pratnji Slavena spalili Salonu. Prvi židovski kvart i sinagoga nalazili su se u istočnim podrumima Palače, sve do požara 1507. g. Nakon toga Get se razvija u sjeverozapadnom dijelu Palače, omeđen ulicama Majstora Jurja, Dominisovom, Bajamontijevom, Rodriginom i Bosanskom (vidjeti u: Vidulić., Priče iz palače by Sandi Vidulić: Židovski Get). O ulicama Geta piše i D. Kečkemet u knjizi Stari Split od kantuna do kantuna Kečkemet D., Borba za grad, Split 2002, str. 70-71; 74-76.

42 Ovo stajalište potvrđuje i Z. Dumanić, op. a.

$43 \mathrm{Uz}$ interpretiranje akcije bojanja Peristila kao šale, ona se doživljavala i kao čisti vandalizam, bez ikakve umjetničke vrijednosti. 
godine u splitskom časopisu za kulturu „Vidik“ manifest „Šest stranica Crvenog Peristila“. ${ }^{44}$

Iako postoje živući akteri, najvjerojatnije je da ovaj urbani mit nikada neće biti u potpunosti razjašnjen. Prije elaboracije spomenutih teza, treba podsjetiti da je akcija bojanja Peristila predstavljala iskorak u postmodernu, ali je važno da je u sebi sadržavala i neke ključne komponente konvencionalne moderne umjetničke intervencije. Naime, poveznice aktera bojanja Peristila i konceptualističke prakse jugoslavenske umjetnosti su sljedeće:

akciju je izvela grupa, a ne pojedinac, što je bilo u skladu s kolektivističkim ideološkim imperativom ondašnjeg sustava,

u tom smislu razumljivo je pozivanje autora na kolektivnu odgovornost,

to potvrđuje potpisivanje svojevrsnog umjetničkog manifesta, te

ideološka konotacija odabira jarko crvene boje.

Navedena akcija ubrzo je prerasla u urbani mit, kao prvi performans i umjetnička intervencija u gradski prostor na području socijalističke Jugoslavije, kojemu je posebnu težinu dao opisani kontekst 1968-me godine. Kako ništa vezano za Crveni Peristil nije jednostavno, tako ni dogovor o boji kojom će se Peristil obojati nije bio jedinstven i jednoznačan. Naime, bilo je mnogo prijedloga kako prebojati Peristil. Jedni su predlagali da se oboji u revolucionarnu narančastu, zatim u anarhističko crno-crvenu, a najkontroverznija je bila Sumićeva ideja da naizmjence obojaju kvadrate u crveno-bijeloj varijanti, aludirajući na hrvatski grb. Naposljetku, a djelomično zbog jednostavnosti izvedbe i dostupnosti boje, odlučili su se za krvavo crvenu.

Postepeno se otkrivaju naznake zašto smo prihvatili kompromisni zaključak o motivaciji intervencije u prostor Peristila, objedinivši likovno-umjetničke i ideološko-političke motive. S jedne strane, čin bojanja Peristila ne može ,pobjeći“ od etikete umjetničkog performansa i prve konceptualne akcije. S druge strane, penetracija u javni spomenički prostor nulte kategorije ukazuje na društvenu angažiranost akcije. Obojani Peristil postao je

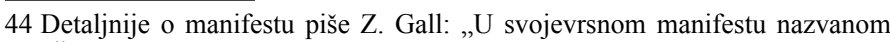
"Šest stranica Crvenog Peristila" Dulčić i potpisani članovi Crvenog Peristila pitaju se, doduše, i o razložnosti umjetničkog djelovanja ako je ono izmješteno iz društvene stvarnosti, no prije će biti da su te teze bile potaknute neposrednim događanjima u vlastitoj sredini nego nadahnute tada aktualnom "novom umjetničkom praksom" (Gall, Peristil-Mladalački bunt ili umjetnost?). 
društvena reakcija aktera na vladajući sistem, odnosno refleksija građanske svijesti na tadašnje odnose u društvu i pripadajući sustav vrijednosti. Lokacija Peristila, kao glavnoga simbola tisućljetne povijesti Splita, bila je savršena za umjetničku refleksiju društvene klime. Iako je većina aktera ustrajala na verziji prema kojoj je bojanje Peristila bio isključivo spontani čin, primjetna je disonanca u toj verziji, jer sami tvrde kako su akciju pripremali najmanje dva mjeseca. Kroz taj period, nastojeći ne biti sumnjivi, u trgovini u centru grada u razmacima su kupovali po kilogram-dva crvenog olovnog minija, sakupivši oko trideset kilograma boje. Činjenica da je postojala dvomjesečna skrovita priprema demantira tezu o spontanosti bojanja Peristila i ukazuje na prisutnost duljeg i intenzivnijeg promišljanja ideje i njenih posljedica.

Prema Sumićevom svjedočanstvu, akcija se trebala odraditi u noći sa devetog na deseti siječnja. Međutim, zbog nepovoljnih vremenskih uvjeta akcija je odgođena za iduću noć. Tako su jedanaestoga siječnja, u rano jutro i po jakoj buri, s metlama $u$ rukama izašli iz potkrovlja u Alešijevoj ulici u Getu i u nekoliko minuta obojali cijeli plato Peristila. No, taj čin nije prošao bez svjedoka. Prvo ih je zaustavio slučajni prolaznik kojeg su uvjerili da pripremaju Peristil za snimanje filma. Pola sata kasnije naišao je milicionar-pozornik i o tom dogaðaju izvijestio je dežurnu službu Javne sigurnosti SUP-a. Organizatora je prema Sumiću bilo osam, a prema Dodigovu svjedočanstvu bili su prisutni on, Sumić i Roje. Međutim, Dodig i Roje su odbili sudjelovati u happeningu smatrajući ga političkim aktom. No, kasnije su prisvojili čin ispiranja boje s Peristila i tu su akciju prozvali „Krvava Neretva“. To je bilo aludiranje na bitku na Neretvi, što se moglo smatrati sarkazmom i podbadanjem. No, Trokut to tumači na sljedeći način: “...drugi se dio akcije odnosi na čin kad su ispirali boju, a radilo se o golemim količinama vode koje su se slijevale u podrume Dioklecijanove palače. Tu akciju koja je bila izvedena kao umjetnička akcija mi posvajamo; dakle, na temelju jednoga sačinjavamo drugo, i ta akcija se zove Krvava Neretva. Tako je mi - Pavao Dulčić, V. D. Trokut, Božidar Jeliniæ, Toma Ćaleta i Filip Roje - tretiramo kao svoju s tog razloga što mi slojevito pretpostavljamo izvjesne konotacije koje su metafizičke; zanima nas onostranost, ono što je s onu stranu stvari, tako da je riječ na jedan način o redizajnu" ${ }^{\prime 45}$.

Što se tiče posljedica, postoji verzija gdje je jedan cijeli dan milicija čuvala aktere Crvenog Peristila u Galeriji Galić da ih ne bi rastrgala pobješnjela svjetina. Službena verzija glasi da ih je

45 Marjanić S., Razgovor s Vladimirom Dodigom Trokutom. Mistifikacija kao medij, 07. siječnja 2011, http://www.zarez.hr/225/kazaliste2.html 
milicija uhitila veoma brzo, te da su kažnjeni novèanom kaznom od 5000 tadašnjih dinara (u današnjoj protuvrijednosti to bi iznosilo oko 50 eura). Ovaj događaj uzbudio je ne samo učmalu svakodnevnicu Splita, već cijelu bivšu državu, a u obranu mladića stali su mnogobrojni ugledni umjetnici i intelektualci. Među prvima je bio njihov profesor A. Kaštelančić, povjesničar umjetnosti C. Fisković, umjetnici M. Kocković i E. Murtić, novinar „Vjesnika u srijedu“ I. Mandić i drugi.

U skladu sa spomenutim imperativom postmoderne „,biti drukčiji, biti prvi“, šokantna akcija je izazvala mnoštvo reakcija na umjetničkoj, intelektualnoj i političkoj sceni. Između ostaloga, dolazi do „rošade“ pojedinih umjetnika i stvaranja nekoliko novih umjetničko-intelektualnih grupacija. Nedugo nakon akcije bojanja prestaje postojati „Grupa Crveni Peristil“ i formira se „Frakcija Crveni Peristil““. Ona potom evoluira u poetsku „Grupu 68“, čiji je fokus bio usmjeren na fenomen sjedinjenja mistike i poetike, te metafizičkih i magijskih formulacija. Unutar ove grupe došlo je do razilaženja na što ukazuje događaj na Festivalu kratkometražnog filma održanom 1969. god. Naime, samo za potrebe akta protesta, koji se izrazio pljeskanjem tijekom projekcije kratkometražnog filma F. Roje u splitskoj kinoteci „Zlatna vrata“, oformljena je „Grupa 30“. Kasnije je iz te grupe nastala „Grupa 3i“ i na koncu grupa „Manifest 72“.

Osim “prestrojavanja” umjetnika, članovi „Grupe Crveni Peristil" nisu zastali na bojanju carskoga trga. Naime, oni su izveli još niz akcija poput one nazvane "Lebdeći spomenik Lenjinu", kada su fontanu na Rivi napunili praškom za pranje rublja i u vodu ulili crvenu boju. Zatim su, odjeveni u narančaste košulje, nosili plakate antibienalskog sadržaja na venecijanskom Biennalu, a sudjelovali su i u spomenutom ,incidentu pljeskanja“ tijekom projekcije filma. Osim akcija koje su uspjeli realizirati, imali su niz ideja, poput razapinjanja konca od Splita do Brača, te omatanja pojedinih splitskih nebodera i spomenika Grguru Ninskom.

\section{Kako je ,crveni Peristil“" posvađao splitsku umjetničku scenu}

Dotjerajte se. Ostavite lažno ime. Budite legendarni. Najbolji poetički terorizam je protuzakonit, ali ne dozvolite da vas uhvate na djelu. Umjetnost kao zločin; zločin kao umjetnost.

\section{Hakim Bey, Poetic Terrorism}

Kao što je rečeno, akteri akcije Crveni Peristil bili su pojedinci slobodarskoga duha, čija su umjetnička stremljenja bila $u$ skladu s globalnim utopijskim akcentom nemirne 1968-me. Ta 
sinergija energija, koje su zazivale oslobođenje čovjeka u vidu samoostvarenja i individualizacije, naišla je na otpor u učmaloj splitskoj sredini. Akt bojanja Peristila primarno je shvaćen vandalističkim činom i napadom na tadašnju društvenu harmoniju. No, iskorak u postmodernu umjetničku zbilju, osim etiketa vandalističkog čina, šale političkih funkcionara, društvene provokacije, mladenačke ludosti, umjetničkog napada na prolaznike i umjetnike, te na monotono lice Peristila, okarakteriziran je i magijskim činom protagonista u mističnom ozračju. Naime, ovakav "samurajski" način promišljanja i rađanja ideja možda je bio pod presudnim utjecajima trenutačnog raspoloženja, pa i konzumacije halucinogena. Upravo moguća upotreba halucinogenih droga dodala je dozu misticizma događaju, čemu su posebnu težinu dale kasnije interpretacije samoubojstava dvaju ključnih aktera akcije (P. Dulčića i T. Čalete). Prema nekim tumačenjima, svjesne akcije suicida trebale su poslužiti u svrhu analize smrti umjetnika. Umjetnička praksa pod utjecajem halucinogena bila je motivirana konstatacijom kako se svijet, unatoč svemu, ne može promijeniti. Stoga je tako shvaćena umjetnost imala za cilj istraživanje inicijacije, oblika svijesti i svjesnosti, te promicanja ideje „nemijenjanja svijeta“. Članovi Grupe smatrali su da čovjek sam po sebi spava i da je mrtav, što se povezuje s kultom A. Crowleya, pa se smatra da su oni bili među prvima u Hrvatskoj koji su se bavili tom okultnom praksom. Pod metodom izlječenja svijesti podrazumijevala se praksa konstrukcije produbljenja svijesti i postizanja zasebnog stanja uma. Takvo buđenje svjesnosti kroz umjetničku praksu u teoriji je trebalo dovesti čak i do izmjene zatečenog društveno-političkog stanja. Glavni protagonisti bojanja Peristila (P. Dulčić i T. Čaleta) svoj su, izvanjskim okolnostima uvjetovani život, okončali protestnim akcijama suicida. Čaleta 1972. godine izvodi performans radnog naslova "Ja sam umjetnik": objesio je oko vrata pločicu s navedenim natpisom i bacio se s trinaestoga kata splitskog nebodera. Slično je postupio P. Dulčić, koji se 1974. godine bacio pod vlak, namjeravajući izvesti analizu smrti umjetnika. No, njegov pokušaj suicida završio je neuspjehom i smješten je $u$ psihijatrijsku bolnicu, gdje umire od posljedica trovanja nakon amputacije noge.

Iz navedenoga je vidljivo da nije samo splitska društvena scena bila nespremna za umjetničku intervenciju takvoga tipa. Naše je mišljenje da za ovako šokantan iskorak u postmodernu nisu bili spremni ni sami akteri akcije. Međutim, neprijeporna je činjenica da opisani umjetnički čin predstavlja temelj urbane splitske scene, pa je tim žalosnije što mu se, uslijed brojnih oprečnih interpretacija, ne daje zasluženo mjesto u povijesti hrvatske umjetnosti. Razlozi brojnim i višeznačnim interpretacijama bojanja Peristila proizvod su činjenice da su članovi grupe Crveni 
Peristil akcije kreirali principom kodeksa, a ne umjetnosti. ${ }^{46}$ Bez obzira na tu činjenicu, oni su uspjeli u svome naumu, jer je ova urbana legenda i danas tema promišljanja intelektualnih

krugova, ne samo u Hrvatskoj nego i izvan njenih granica.

Ignoriranjem od strane domaćih umjetničkih i intelektualnih elita, akcija bojanja Peristila baca se na margine umjetničkoga. Moguće je da su tadašnji splitski umjetnički krugovi zamjerili grupi Crveni Peristil dobivenu blagu novčanu kaznu, protumačivši je dokazom nerevolucionarnosti samoga čina. Na tragu navedenog su i razni komentari, pa čak i međusobni okršaji živućih aktera poput S. Sumića na jednoj i Z. Dumanića i V. Dodiga-Trokuta na drugoj strani. To je bilo vidljivo na ,21. Adria art analleu“ koji je održan u listopadu 2008. god., točnije na predavanju pod naslovom "Crveni Peristil i falsificiranje umjetnosti". Isto tako, začuđujuće je da se tek na manifestaciji posvećenoj Crvenom Peristilu „,+40“, održanoj u beogradskom Centru za kulturnu dekontaminaciju, čuo glas B. Jelinića koji je konstatirao kako je P. Dulčić bio jedini njegov istomišljenik i umjetnički suputnik, a ostale aktere nazvao je „nevažnim asistentima“. Zaključio je kako je Grubićev Crni peristil iz 1998. godine jedini “....autentični hommage Crvenom Peristilu koji je imao vjerodostojni kontinuum i direktan politički utjecaj" ${ }^{47}$.

Koliko daleko može ići splitski jal, najbolje oslikava Dumanićevo viđenje akcije Crveni Peristil: ,,...nemate boljega svjedoka od mene ili Vladimira Dodiga-Trokuta. Mogu svjedočiti tako da je usporedo s Crvenim Peristilom, dakle, Dulčićem i kompanijom, djelovala grupa 3i u Luxoru u kojoj sam se našao s Trokutom i Grubišićem. Apsolutno nismo imali kontakte s Dulčićem, kao grupom netalentirane klateži... Nas trojica shvatili smo situaciju s obzirom da je Trokut bio u udbaškim vodama po očevoj strani. Baja, zaslužni Splićanin i čuveni Titov komunistički povjerenik za Split i direktor Škvera, inače, jako lucidan čovik, bacio je tim klatežima ideju kako Rusi, Sovjeti imaju Crveni trg, te zašto i mi ne bismo imali crveni Peristil: "Umjesto da nešto radite, vi fumate!" Dakle, riječ je o njegovoj apsolutnoj vrijednosti u iniciranju te akcije. I klatež je kupila boju. Tada je, naročito, Trokut bija informiran s Umbertom Ecom, djelovala je grupa OHO... Drugo je kasnije pitanje SDP-a, linije komunističkoga crvenoga koja devedesetih izdaje na čelu sa Svemirom Pavićem izložbu o Crvenom Peristilu. I što se događa: tu imate dvadesetak očajnih radova diletantizma najgore vrste... Priča o nekoj radikalnosti grupe Crveni Peristil apsolutno je jedan mit koji je, istina, jako

46 Članovi Crvenog Peristila svoje akcije nisu ni na koji način arhivirali, jer su smatrali da arhivu čine sami autori.

47 Opširnije vidjeti u: Pažin-Laušić V., Uz 40. obljetnicu crvenog i 10. obljetnicu crnog Peristila, Pariz, Prag, Peristil. 
koristan i koji ću osobno uvijek braniti, ali ipak na jedan drugi način s obzirom na to da su se Crvenim Peristilom napajale generacije umjetnika i zbog toga taj mit ne želim rušiti na taj način, ali istina je da je riječ o slabašnim umjetnicima, netalentiranima od kojih se napravilo čudo. A to da su oni izveli konceptualnu akciju Crveni Peristil, to vam je lagarija - o čemu sam prije rekao - koju naposljetku ne zna samo Trokut ili ja; to znaju i svi oni koji su oko Pavića. I onda sve one lagarije da se Čaleta 1972. bacio s nebodera s pločicom oko vrata na kojoj ispisuje Ja sam umjetnik - da je to bilo konceptualno samoubojstvo, to je čista lagarija. Ti netalentirani klateži ubili su se jedan po jedan bez razloga a ne protiv nekoga mita, što isto tako dokazuje i samoubojstvo Kravice koje je narkomansko i alkoholičarsko samoubojstvo. Ubili su se jer nisu bili umjetnici; nisu znali prevladati kaos u sebi i oko sebe ${ }^{\text {“48 }}$.

\section{Zaključak}

Kazali smo da je kultura zajednička svim pripadnicima određenog društva, kao trajna, prilagodljiva, organizirana i integrirana kategorija koja, između ostaloga, ima ulogu propisivanja prihvatljivog ponašanja. Kultura kao društveno vezivno tkivo egzistira u simbiotičkom odnosu s nacijom u smislu da integralne elemente nacionalnog identiteta sačinjavaju jezik, etnička i kulturna srodnost, te religija.

U suvremenom kontekstu nacije - države harmonizacija više nije imperativ, nego se traže politièki osjetljiva kompromisna rješenja konflikata koji se javljaju među društvenim akterima. Iako su rješenja bitno različitog sadržaja od onih primjenjivanih u prošlosti, ona također dovode do stabilizacije i homogenizacije društva. Ukoliko se različitosti i konflikti potiskuju, oni ubrzo postaju „bumerang“ koji može potaknuti oživljavanje partikularnih, pa i totalnih vidova različitih ideologija. $U$ tom slučaju, ideologija više nije „omotač“ društva, nego se pretvara u prijeteću silu koja, prožeta propagandom, prerasta u teror nad dijelovima društva ili nad društvom u cjelini. Budući da se ideologija i zbilja na taj način kreću jedna prema drugoj i da zbilja, u nedostatku neke druge uvjerljive ideologije, postaje ideologijom za sebe, bio bi potreban samo mali duhovni napor da se zbaci svemogući i ništavni ideološki privid. No, čini se da je taj napor upravo ono što je najteže učiniti u suvremenim društvima. ${ }^{49} \mathrm{U}$ članku je iznijeta Marxova i Engelsova tvrdnja da grad predstavlja aktivni dio naše civilizacije i, stoga ga percipiramo kao

48 Vidjeti u: Marjanić S., Razgovor s Zlatanom Dumanićem, Umjetnik je labirintičan čovjek, 07. siječnja 2011., http://www.zarez.hr/152/kazaliste2. htm

49 Adorno T.W. i Horkheimer M., Sociološke studije, Zagreb 1980, str. 184. 
središte duhovnih aktivnosti. Isto tako, kazali smo da nijedan prostor ne odražava toliku ambivalentnost kao gradski prostor koji je, s jedne strane, mjesto sigurnosti, kreativnosti i zaštite individualnih vrijednosti, a s druge strane je mjesto represije,

kontrole, pokoravanja i društvene segregacije.

Slučaj Crvenog Peristila, odnosno penetriranje u urbani prostor umjetničkom intervencijom bojanja znamenitog trga crvenom bojom, ne može se interpretirati kao suludi čin mladenačkog vandalizma ili patetični pokušaj nesuđenih umjetnika da ostanu zabilježeni u almanahu suvremene umjetnosti. Kad bismo i prihvatili navedene ocjene ili kad bismo akciju shvatili kao političku šalu, društvenu provokaciju ili okultni obred, jedno je neminovno: ovim umjetničkim činom, te svime što mu je prethodilo i što je potom uslijedilo, otpočela je nova umjetnička praksa u Hrvatskoj. O tom novom obliku umjetničke prakse S. Sumić, jedan od rijetkih aktera koji je istupao u javnosti, rekao je sljedeće: “...umjetnost je bitan element civiliziranog društva. Mene zanima umjetnost $\mathrm{u}$ odnosu na društvo, kao jedan element kolektivnog pročišćenja. U tu svrhu koristim različita iskustva i medije. Danas je to performans, sutra kazalište, slika... Razlika između performansa i slike je u tome što performans modelira direktnu stvarnost $\mathrm{i}$ ostaje $\mathrm{u}$ vremenu te preživljava jedino kroz video ili foto dokumentaciju, dok slika, skulptura, crtež, ostavljaju dublji materijalni trag te ostaju prisutni dok god se materijalno ne unište. Ono što je najvažnije u cijeloj toj igri je to kakvog traga umjetnost ostavlja u nama" ${ }^{\text {". }}$. Dakle, Crveni Peristil nije neutralni apstraktni komentar i intimna individualna priča, nego je odgovor na duhovni prostor toga vremena, koji je bio refleksija stanja građanske svijesti, reakcija i svojevrsni otpor grupnog identiteta postojećoj ideologiziranoj društvenoj zbilji. Tako hrvatski performer Tom Gotovac tvrdi da 1968-me na Peristilu “... crvena boja nije bila slučajna... To nije bila crvena boja nego pobuna; to je crvena boja koju je izmislio Jean-Luc Godard, boja anarhije, što je Grubić shvatio i 1998. dodao joj drugu anarhističku boju - crnu" ${ }^{\prime 1}$.

Možemo zaključiti: kultura kao tvorevina duše, nacija kao ogledalo duše i ideologija kao suton duše, tri su komponente duha jednog naroda. No, kad duh naroda zapadne u stanje apatije, na scenu stupa praksa duše u vidu umjetnosti. Ova posljednja komponenta zaprema dijalektički janusovski karakter, balansirajući na ljestvici omeđenoj dvjema krajnostima: prva je društvena stabilnost koja vezuje tkivo društva, a druga je krajnost ,,̌̌etvrti

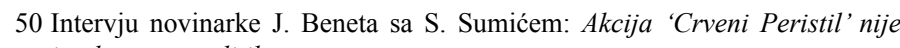
imala veze s politikom.

51 Iz članka Uz 40. obljetnicu Crvenog Peristila i 10. obljetnicu Crnog Peristila, Pariz, Prag, Peristil. 


\section{S. ČOKOLIĆ, Z. GRUBIŠIĆ i N. DUVNJAK}

jahač apokalipse“ koji dezintegrira društvo. Akcija Crveni Peristil bila je negdje po sredini ove ljestvice: važan umjetnički čin

koji je uznemirio uspavani duh Splita.

\section{LITERATURA:}

Adorno T.W. i Horkheimer M., Sociološke studije, Zagreb 1980.

Bavčević Đ., Crveni Peristil, seminarski rad, Umjetnička akademija, Sveučilište u Splitu, Split 2009, str. 3.

Beck U., Pronalaženje političkog-prema teoriji refleksivne modernizacije, Zagreb 2001.

Čolić S., Kultura i povijest, Zagreb 2002.

Fanuko N., Sociologija, Zagreb 2005.

Fromm E., Zdravo društvo, Zagreb 1989.

Haralambos M. i Holborn M., Sociologija-teme i perspektive, Zagreb 2002.

Jenkins R., Social Identity, London 2007.

Jukić J., Lica i maske svetoga, Zagreb 1997.

Kečkemet D., Borba za grad, Split 2002.

Knežević R., Načelo slobode i politički poredak. Politologijski ogledi o liberalizmu, totalitarizmu i demokraciji, Zagreb 2007.

Mannheim K., Ideologija i utopija, Zagreb 2007.

Simmel G., Kontrapunkt kulture, Zagreb 2001.

Supek R., Društvene predrasude i nacionalizam, Zagreb 1992.

Vrcan S., Nacija-nacionalizam-moderna država: između etnonacionalizma, liberalnog $i$ kulturnog nacionalizma ili građanske nacije $i$ postnacionalih konstelacija, Zagreb 2006.

\section{Izvori s interneta:}

Bey H., Poetic Terrorism, 03. siječnja 2011, http://sniggle.net/Manifesti/poeticTerrorism.php

Beneta J., Akcija „Crveni Peristil“" nije imala veze s politikom, 04. siječnja. 2011, http://www.glasdalmacije.hr/?show $=0 \&$ article $=8900$

Crveni Peristil 1968-2008 (40 godina provokacije), 03. sijeènja 2011, http://nesvrstani.blog.hr/2008/01/1623984926/crveni-peristil-1968-

2008-40-godina-provokacije.html

Franulić M., ,... ono što je prethodilo Crvenom Peristilu...“, 04. siječnja 2011,

http://www.kulturpunkt.hr/i/najave/1968/

Galerija Nova predstavlja Crveni Peristil i ono što mu je prethodilo, 05. siječnja 2011, http://www.dnevnikulturni.info/vijesti/ 
likovnost/905/galerija_nova_predstavlja_crveni_peristil,_i_ono_sto_ mu_je_prethodilo/

Gall Z., Peristil - Mladalački bunt ili umjetnost?, 07. siječnja 2011, http://www.jutarnji.hr/peristil-mladalacki-bunt-ili-umjetnost-/239469/

Grupa autora, 1968. trideset godina kasnije, 07. siječnja 2011, www. stocitas.org/1968.htm.

Marjanić S., Razgovor s Zlatanom Dumanićem, Umjetnik je labirintičan čovjek, 07. siječnja 2011, http://www.zarez.hr/152/ kazaliste2.htm

Marjanić S., Razgovor s Vladimirom Dodigom Trokutom, Mistifikacija kao medij, 07. siječnja 2011, http://www.zarez.hr/225/kazaliste2. html

O.T.O.Crowley, 03.siječnja 2011., http://www.kockicica.org/blog/ otocrowley-razno

Pažin-Laušić V., Uz 40. Obljetnicu crvenog i 10. Obljetnicu crnog peristila Pariz, Prag, Peristil, 06. siječnja 2011,

http://www.slobodnadalmacija.hr/Hrvatska/tabid/66/articleType/ ArticleView/articleId/22154/Default.aspx

Političke prakse (post)jugoslovenske umetnosti: retrospektiva, 05. siječnja 2011,

http://pp-yu-art.net/uvod

Razgovor s Vladimirom Dodigom Trokutom, 05. siječnja 2011, http://www.forum.hr/showthread.php?t=125336\&page=2

Vidulić S., Priče iz palače by Sandi Vidulić: Židovski Get, 05.01.2011, www.slobodnadalmacija.hr/Split/tabid/72/articleType/ArticleView/ articleId/96455/Default.aspx 
Sanja Čokolić, Zorica Grubišić and Neven Duvnjak

University of Split, Faculty of Philosophy - Department of Sociology, University and Study Center for Phorensic Sciences;Department for Phorensics and National Security, Split, Croatia

Institute for Applied Social Researches Ivo Pilar - Center, Split, Croatia

\title{
RED PERISTILE: BETWEEN SOCIAL PROVOCATION, ARTISTIC ACT, URBAN MYTH, AND SPLIT'S JEALOUSY
}

\begin{abstract}
This article analyses the action of painting Split's Peristile in red color, which happened in January 1968. The Peristile is in the central square of the well known Roman Diocletian's Palace, around which the modern town of Split has formed. In the first part of the article, authors theoretically discuss the influence of culture, nation and ideology on social and spiritual reality. As far as culture is concerned, two components are emphasized. The first one consists of norms, values, customs, beliefs and behaviors, and the second one refers to the individual in interaction with traditional elements of culture. When speaking about nation, authors stress the influence of politics, because any theoretical definition of the nation legitimizes one sort of political demand, and de-legitimizes others. The notion of ideology and its historical development in the West is more extensively discussed, with emphasis on Mannheim's differentiation of particular and total notion of ideology. Having in mind the town in general, authors discuss it as a place of co-existence of architecture, habits and people. Culturalcivilizational characteristics of modern cities as well as the state of mind in Split in 1968 are elaborated. After a theoretical introduction, and on the basis of a great number of resources, the process of Peristile painting is presented in detail. The manner in which this artistic performance was carried out is extensively described. This part of the article is supplemented with biographies of artists who directly or indirectly participated in the mentioned performance. Among other things, it turned out that protagonists still cannot agree as to who constituted a group called "The Red Peristile Group". There are also disagreements about the motifs for painting the Peristile red. Some of them considered it was a pure artistic act and others - an ideological and political action. References are made to the sharply opposed reactions of artist, politicians, and intellectuals towards the shocking act. Some of them have qualified it as an act of vandalism, a joke of political officials, youth folly, and even an occult act under the influence of drugs. Conclusion can be drawn that the action "The Red Peristile" was an important artistic performance which has disturbed a lethargical state of mind in Split of that time.
\end{abstract}

Key words: "Red Peristile" Group, 1968, culture, nation, red color, visual art action 